\title{
3D Animation for Transferring Technology to the Community in Rural
}

\author{
Ambar Yoganingrum, Wahyoe Soeprihantoro, Agusto W. Martosudirdjo, and Ira Maryati
}

\begin{abstract}
Face to face meeting is the most common way in technology transfer, especially being addressed to the rural community. It becomes challenge for Indonesia as an archipelago country, since transportation and commonication system is still in the difficulty. It requires a media that is not constrained by the distance and time but low cost. This research aims to analyze the usage of $3 \mathrm{D}$ animation for transferring technology to the rural community as well remote area. The technology in this research is an appropriate technology consisting of solar drying cabinet (SDC) and sealer as well as reservoir. Meanwhile the community is people who live in Tanjung Batang Island, a small Island in Indonesia. Interview and observation are employed in data collection. The result shows that the content of the media has to be revised by using local terms as well as more focused and detailed. The conclusion is that 3D animation could be a prospective media for transferring technology to the rural community without assistance.
\end{abstract}

Index Terms-3D animation, multimedia, rural community, technology transfer.

\section{INTRODUCTION}

Face-to-face meeting such as training, workshop, visiting, excursion, and assistance are common ways for transferring technology to the people in rural. Researchers in Indonesian Institute of Sciences (LIPI) transfer an appropriate technology to SMEs through assistance and continuous interaction [1], [2]. Meanwhile the program for building community capacity in creating children's healthy and positive environments uses visiting, excursion and workshop [3]. In the meantime one of activities to overcome the failure of hand pumps implementation in South Africa is by providing training [4]. Workshop, training and technical assistance are employed to transfer technology from university to rural industries in developing countries [5].

People in rural may rely on oral and other non-written sources for information [6]. Indonesian people in rural also prefers to information provided with oral [7]-[9]. The

Manuscript received August 9, 2016; revised December 28, 2016. This work was supported by the Indonesian Institute of Sciences under Program Riset Unggulan 2015-2017.

Ambar Yoganingrum and Ira Maryati are with the Center for Scientific Documentation and Information, Indonesian Institute of Sciences, Indonesia (e-mail: ambaryoganingrum@gmail.com, iramaryati@gmail.com).

Wahyoe Soeprihantoro is with Research Center for Geotechnology, Indonesian Institute of Sciences, Indonesia (e-mail: wshantoro@ gmail.com).

Agusto W Martosudirdjo is with The Center of Appropriate Technology Development, Indonesian Institute of Sciences, Indonesia (e-mail: agustow@gmail.com). technology, which introduced by oral tradition circumstances in rural can create satisfactory outcomes [10]. However face-to-face meeting technique in transferring technology becomes constraint for Indonesia, which the people are spreaded out on islands. The technique is limited by the distance, cost and time. In addition the number of researchers is very limited compared to the number of the people who requires.

The rapid development of ICT has created media, which is able to visual information and convey it orally. Animation has great potential to improve human learning especially when the goal is to promote deeply understanding. Due to words and pictures are working simultaneously in memory hence learners are better able to make mental connections between them [11]. On line learning based an animation significantly increases an ability to construct and adapt to scientific and technological knowledge as well as the motivation for learning science and technology [12]. 3D animation becomes tool of choice to convey information for people, who illiterate or difficulty in understanding written information [13]. Multimedia learning animation has the finest and positive impact in understanding a concept easily and memorable [14], [15]. Additionally any kinds of animation such as static graphics, 2-D, and 3-D are not significantly different in influencing learning process [16].

Animation is applied in learning of some disciplines among others are nuclear technology [17], education [18], e-learning [19], engineering [20], biology molecular [21], disaster risk management [22] and linguistic [23]. 3D animation also is employed as a tool for understanding manuals [24], analyzing the sport event [25] and documenting the ancient art [26]. Animation has been studied as a tool for transferring knowledge to student [12] and cross generation [27]. However there is a lack of research, which analyzing animation as a tool for transferring technology to the community. Accordingly this study aims to analyze the usage of 3D animation for transferring technology to the community in rural. This research focus on the potential of 3D animation as an technology transfer tool. The research questions after watching 3D animation of reservoir, are following (1) Do the participants understand the content? (2) How is the understanding of people? Then the question related to the animation of SDC technology, does the participant understand and are they able to build the technology?

The urgency of this researh is finding a technology transfer media, which is potential to overcome the constraints of distance, cost and time as well as limited numbers of researchers to convey the technology with face-to-face meeting. 3D animation could be reach out many users by uploading on the web. It could be disseminated also through email or mobile phone directly to the users. 


\section{MethodolOGY}

\section{A. Creating 3D Animation}

The moviemaker creates 3D animation. Script is built together between moviemaker and the researcher. The process in making animation takes about 3 months. The animation is made in two versions, long and short version. Long version is uploaded on web and compact disc. Meanwhile short version can be disseminated through mobile communication. The stages in making animation are in Fig.1. Meanwhile the covers of animation are presented in Fig. 3. We build two titles of animation namely solar drying cabinet and sealer (two technologies in a one single film) and reservoir.

\section{B. The Topic of 3D Animation}

The topic of 3D animation is about appropriate technology consist of building solar drying cabinet (SDC) and sealer as well as constructing ground reservoir. SDC has a function to dry marine products, such as fish, seaweed, squid and so on using sunlight. Meanwhile sealer is a tool for welding plastic packaging. Ground Reservoir (called embung) has a function to store water that comes from springs. The choice of topics based on the need of the people taken by interview and observation.

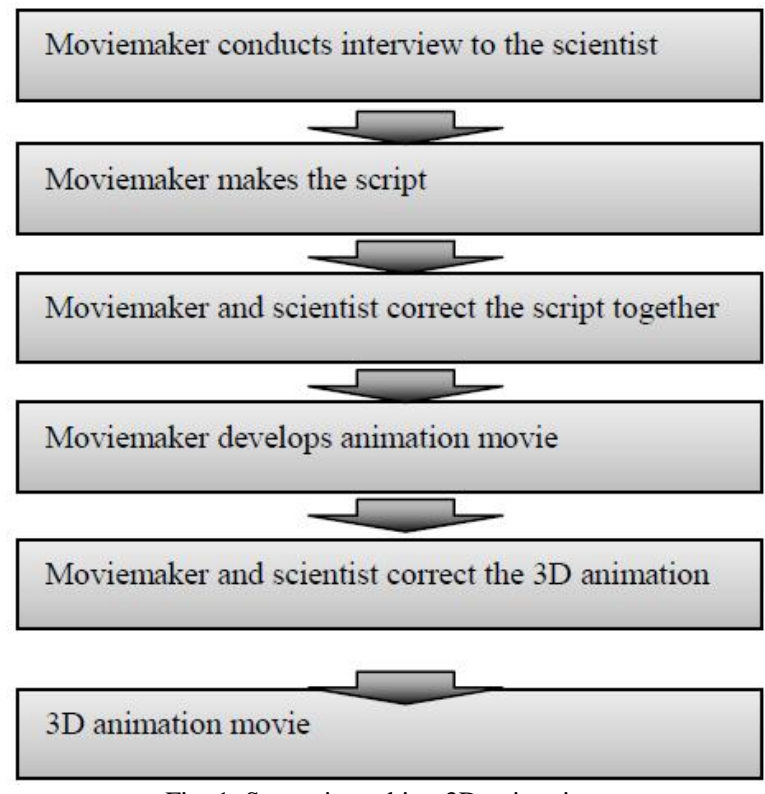

Fig. 1. Stages in making 3D animation.

\section{Data Collecting}

The constructing of reservoir is much more expensive than the building of SDC and sealer. Accordingly the group of participants shows the animation of reservoir without construction. Afterwards the researcher asks a question and notes the question asked by them.

The other group of participants shows the animation of SDC and then a participant goes shopping for the materials. The distance between the village and the shop is one hour boating and 1,5 hours driving one way. Next others build SDC. The participant can ask to the researcher during purchasing and three days working in building SDC. There is a participant, who has woodworking skills naturally. $\mathrm{He}$ becomes a group leader. The leader forms smaller groups.
They discussed to determine the working order, the type of material required and share the tasks among smaller groups. The researcher observes their activity and notes all questions asked by the participants.

\section{Testing Stages}

1) $3 D$ animation of the manufacturing of SDC and sealer

Firstly the animation is emailed to a participant. The participant interprets the kind and amount of material required through the animation. Then researcher transfers the budget to the participant to buy the material required. A group of participants consist of 5 persons works for making SDC. The shopper does not participate in making SDC. Prior to work, all participants watch the animation together. Fig. 2 shows the participants are working.

\section{2) 3D animation of the constructing of reservoir}

Firstly the group of participants consisted of four participants watched 3D animation of constructing reservoir together. The animation contains the following information: the water cycle in a small island, the explanation why the island is suffering water shortages in the dry season, why ground reservoir is necessarily required to overcome the problem, and how to construct and maintenance the reservoir. After watching together, researcher asked open-ended question to the participants, whether the participants could understand the content of the animation.

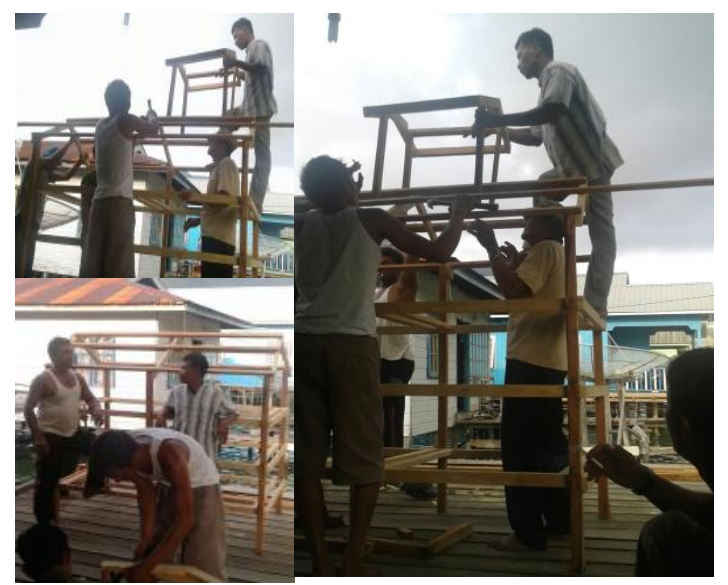

Fig. 2. Participants are making solar drying cabinets.

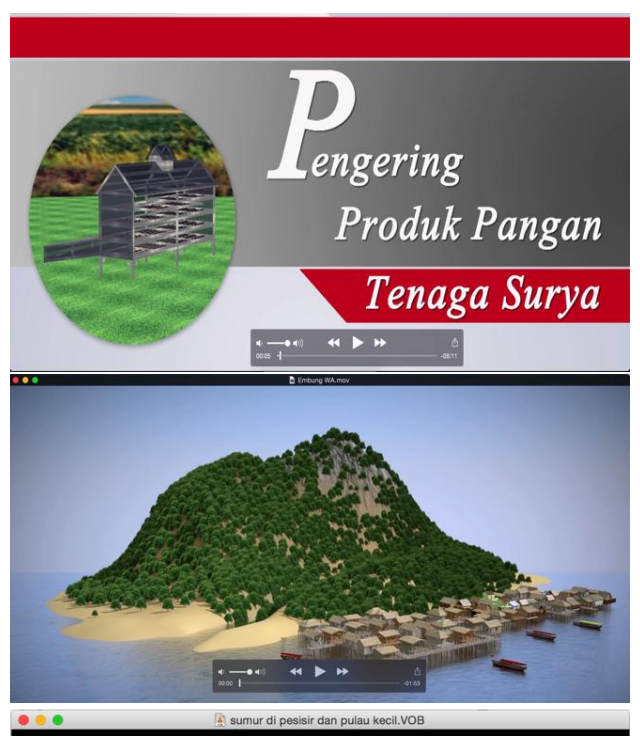

Fig. 3. 3D animation cover. 


\section{E. Research Locus and the Participants}

The participants are the people living in the village of Tanjung Batang, sub-district of Pulau Tiga, District of Natuna, Indonesia. The participants are mostly fishermen.

Sub-district Pulau Tiga is expanding as a Minapolitan area. It means the region is expanding with the concept of fisheries sector.

\section{INSTITUTIONS PROFILE}

\section{A. Center for Scientific Documentation and Information (PDII) - LIPI}

PDII LIPI is a national center for repository, which has responsibility in processing data and scientific publications nationwide. Additionally PDII LIPI has function in disseminating science and technology to the remote and border areas.

\section{B. Center for Appropriate Technology Development (Pusbang TTG) - LIPI}

The existence of Pusbang TTG is one of LIPI concerns to the development and application of appropriate technology in the field of food, agriculture, energy and the environment, to empowerment the community especially Small and Medium Enterprises (SMEs).

\section{Research Center for Geotechnology $(P 2 G)-L I P I$}

P2G-LIPI has developed a set of low-cost technology to improve resilience on freshwater storage in the aquifer by injecting rainwater for people who live in coastal and small islands. The center also develops an open and close small-scale reservoir for small-island.

\section{RESUlTS AND DISCUSSION}

\section{A. The Understanding of Participants to the 3D Animation of Reservoir}

After watching together participants said that they could understand the content. Then the participants asked following some questions.

- Do reservoir can overcome the problem of water shortage, especially during the dry season?

- Are ponds built near or far from the river flow?

- Is the water stored in the reservoir does not change (quality) and can be used every time?

- How to determine the thickness of the layer of soil?

- Is the bottom of reservoir need covered by cement?

- Is water tank need to be made?

- Does the system need tower reservoir to facilitate distribution?

- How much water can be saved into the reservoir?

- How long the water can be retained?

- How many storage must be developed to serve about 1000 people for their normal daily need.

- How much water can be saved into the reservoir?

The capability to ask questions shows that participants have higher-order thinking skills. The examples of cognitive activities classified as higher-order include constructing arguments, asking questions, making comparisons, solving non-algorithmic complex problems, dealing with controversies and identifying hidden assumptions [28].

\section{B. The Understanding of Participants to the 3D Animation of SDC Manufacture}

Based on the questions asked by the participants, following are the result of research

1) Stage in purchasing materials

- The participant doubts on the selection of material, whether wood or iron.

- No information about the dimensions in animation make participant doubt about the amount of material should be purchased.

The participant chooses material of wood due to price consideration. Wood bar is cheaper than iron bar. The animation is intentionally not including dimensions and standard units, in order to provide space for the user to adjust the availability of space for placing SDC. While participant call the researcher to ask about the dimension of SDC, the researcher uses scale 'meter' for length, while participant uses 'feet'. Community in research locus normally uses 'feet' to length of material. The differences of the length unit term makes confuse participants in determine the amount of the material. Using local term in transferring technology would avoid the confusion. It is likewise a project in Mexico, which provides a user manual in indigenous language for solar cookers to urge consumption reducing of timber by 30\% [29].

2) Stage in Building SDC

- The makergroup understands after the second time of animation screenings.

- Due to the animation of SDC and sealer joint in one single movie, the participants are confused and asking, why electricity needed for SDC. Actually electricity is for sealer.

Content of each animation should be focused. Therefore each animation should consist of a single technology. Participants make a connection between two technologies, if there are in a one single animation. The short and focused messages of animation applied on an experiment is able to prove in promoting learners understanding effectively [11]. In addition learner performs better on problem-solving transfer tests when they studied animation and narration without extraneous words, video, or sounds [11].

3) Following are the requests from the makergroup:

- Providing of detailed information in animation regarding the duration of drying, the capacity of SDC, type of products can be dried by SDC.

- Providing of information regarding the advantages of using SDC.

- Providing of a real model of SDC.

- Providing pamphlet along with the animation, for ease of understanding.

- Animation can be watched on a cellular phone.

Participants required not only the technology itself but also other information such as the capacity, duration of drying, type of product, and the advantages of the technology. The information could be packaged on another animation, separated from the animation regarding manufacturing SDC. The separation is intended to keep the animation focused. 
A real model of technology called mock-up is a tool to transfer knowledge for SMEs [30]. In manufacturing, mock-up is a scale or full-size model of a design or device, used for teaching, demonstration, design evaluation, promotion, and other purposes [31]. Designing mock-up of SDC probably is able to help participants to understand the technology.

Participants need information in the form both pamphlet and on a cellular phone, means that they want to have the information on certain packaging. It also can be assumed that the animation could be an encouragement for people in rural to use written information then.

\section{CONCLUSION}

We conclude that 3D animation containing detailed and focused information could be a tool to transfer technology to the rural community. Additionally, 3D animation will be understood easily if using the local terms. However it is assumed that this result is influenced by that SDC and reservoir are technologies required by the participants. Furthermore the usage of more than one media to transfer technologies such as 3D animation, pamphlets and mock-ups are assumed to be more effective.

\section{ACKNOWLEDGMENT}

We thank Bapak Zuldi, S.Sos, M.Si, head of Tanjung Batang village for his support to this research.

\section{REFERENCES}

[1] E. Marlina and S. Riyanto, Knowledge Harvesting System pada Proses Pengkapturan Alih Teknologi di Lingkungan LIPI, Cibinong, Indonesia: Pusat Inovasi LIPI, In Press

[2] S. Kustantyana, R. Asihanti, and A. Yoganingrum, Media Transfer Untuk Proses Alih Pengetahuan Pada Komunitas Peneliti Di Lingkungan LIPI, Cibinong, Indonesia: Pusat Inovasi LIPI.

[3] S. K. Wortona, R. Caplana, G. Nelsona, S. M. Pancera, C. Loomisa, R. D. Peters, and K. Haywardc. "Better beginnings, better futures: Theory, research, and knowledge transfer of a community-based initiative for children and families," Psychosocial Intervention, vol. 23, issue 2, pp. 135-143, May-August 2014.

[4] Y. A. Barakia, and A. C. Brenta, "Technology transfer of hand pumps in rural communities of Swaziland: Towards sustainable project life cycle management," Technology in Society, vol. 35, pp. 258-266, Nov. 2013.

[5] N. Theodorakopoulos, D. J. S. Preciado, and D. Bennett, "Transferring technology from university to rural industry within a developing economy context: The case for nurturing communities of practice,' Technovation, vol. 32, pp. 550-559, Sep.-Oct. 2012.

[6] R. Catts and J. Lau, "Toward information literacy indicators," Information Society Division, Paris: UNESCO, 2008, pp. 1-44.

[7] Yoganingrum and W. Soeprihantoro, "The information needs and media of small islands society," Komunitas, vol. 7, no. 2, pp. 271-28, Sep. 2015.

[8] Yoganingrum, I. Maryati, and M. Y. Rezaldi, "Kebutuhan dan media informasi pengelolaan air tawar masyarakat di Kepulauan Seribu," IPTEK-KOM, vol.14, no. 2, pp. 151-164, Dec. 2012.

[9] Yoganingrum et al., "Media informasi teknologi pengelolaan air tawar untuk masyarakat pesisir dan pulau kecil di Kabupaten Kepulauan Seribu," Proceeding Lokakarya Nasional Dokumentasi dan Informasi. Pengelolaan Data dan Informasi dalam Perkembangan Teknologi Informasi di Era Big Data, September, pp. 143-164, 2015.

[10] G. V. Stam, "Information and knowledge transfer in the rural community of Macha, Zambia," The Journal of Community Informatics, vol. 9, no. 1, 2013.

[11] E. M. Richard and M. Roxana. "Animation as an aid to multimedia learning," Educational Psychology Review, vol. 14, no. 1, pp. 87-89, March 2002.
[12] Y. Rosen, "The effects of an animation-based on-line learning environment on transfer of knowledge and on motivation for Science and technology learning," J. Educational Computing Research, vol. 40, no. 4, pp. 451-467, 2009.

[13] Maryati and A. Yoganingrum, "Information packaging process for solving the lack of information literacy in coastal and small island areas in Indonesia," in Proc. 16th Congress of Southeast Asian Librarians Meeting and General Conference (CONSAL XVI), pp. 527-532, November 2015.

[14] S. B. Zahra, "Effect of visual 3D animation in education, European," Journal of Computer Science and Information Technology, vol. 4, no. 1, pp. 1-9. January 2016.

[15] C. C. Chiou, L. C. Tien, and L. T. Lee, "Effects on learning of multimedia animation combined with multidimensional concept maps," Computers \& Education, vol. 80, pp. 211-223, January 2015.

[16] R. M. Rias and H. B. Zaman, "Can different types of animation enchance recall and transer of knowledge? A case study on a computer science subject," AJTLHE: ASEAN Journal of Teaching and Learning in Higher Education, vol. 4, no. 1, pp. 32-43, January 2012.

[17] R. B. Jones and M. A. Tavel. "Transferring concepts in nuclear technology with computer generated films," Annals of Nuclear Energy, vol. 4, issue 6-8, pp. 353-368, 1977.

[18] R. Gurvitcha and J. Lunda. "Animated video clips: Learning in the current generation," Journal of Physical Education, Recreation \& Dance, vol. 85, no. 5, pp. 8-17, 2014.

[19] K. K. Bhattacharjee, R. Shankar, and M. P. Gupta, Flexibility in e-Learning through Knowledge Management Practices: A Case Study in Systemic Flexibility and Business Agility, Systemic Flexibility and Business Agility, India: Springer, 2015, pp. 143-164.

[20] K. McMenemy and S. Ferguson, "Enhancing the teaching of professional practice and key skills in engineering through the use of computer animation," International Journal of Electrical Engineering Education, vol. 46, no. 2, pp. 164-174, April 2015.

[21] J. H. Iwasa, "Bringing macromolecular machinery to life using 3D animation," Current Opinion in Structural Biology, vol. 31, pp. 84-88, April 2015

[22] M. Y. Rezaldi and G. M. Perdananugraha, "Multimedia applications for disaster risk management," Teknologi Indonesia, vol. 39, no. 1, pp. 1-14, 2016

[23] R. Li, J. Yu, and Z. Wang. "Collision handling in 3D articulatory animation for Chinese speech articulation," IFAC-PapersOnLine, vol. 48, no. 28, pp. 1047-1052, Dec. 2015

[24] M. Jia, Animation as Instructional Manual: The Effects of Representational and Motivational Animation on Usability, Thesis, Faculty of Behavioural, Management and Social Sciences, University of Twente, Enschede, Netherlands, 2016.

[25] R. M. Angulo, "Animation and analysis of sport events through 3D computer modeling," Journal of Biomechanics, vol. 25, no. 7, p. 761, July 1992.

[26] H. Zhou and S. P. Mudur, "3D scan-based animation techniques for Chinese opera facial expression documentation," Computers \& Graphics, vol. 31, no. 6, pp. 788-799, Dec. 2007

[27] B. McKee, Animating Yanyuwa Narratives: Capturing Intangible Heritage with 3D Animation for the Purpose of Cultural Preservation and the Cross-Generational Transfer of Knowledge, Thesis, Dept. of Design, Monash University, Melbourne, Australia, 2013.

[28] Zohar, "Description of the TSC project in Higher order thinking in science classroom: Students' learning and teachers' professional development," vol. 22, 2004, ch. 1, p. 2

[29] L. B. L. Sosaa, M. G. Avilésa, M. G. Avilez, D. G. Péreza, and Y. S. Gutiérreza, "Rural solar cookers, an alternative to reduce the timber resource extraction through the use of renewable energy sources: technology transfer and monitoring project," Energy Procedia, vol. 57, pp. 1593-1602, Nov 2014.

[30] F. S. Feyertag and V. Pammer, "Designing innovative digital technologies for knowledge management and data-driven business: A case study," in Proc. the 15th International Conference on Knowledge Technologies and Data-Driven Business. $i$-KNOW, October 2015.

[31] Mockup. [Online]. Available: https://en.wikipedia.org/wiki/Mockup

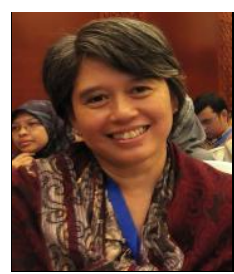

Ambar Yoganingrum received the doctoral degree in information science from University of Indonesia in 2015. She is now researcher in Center for Scientific Documentation and Information, Indonesian Institute of Sciences. Her researches focus on disseminating information and transferring knowledge to the community in rural. 


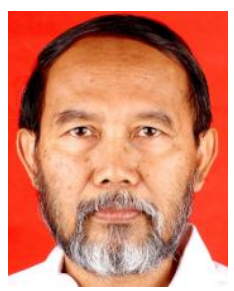

Wahyoe Soeprihantoro is a professor of geodynamics in Research Center for Geotechnology, Indonesian Institute of Sciences. He has developed technology for water management for coastal and small island area since 2002. He received doctoral degree in earth science from Universite D'aix Marseille II France.

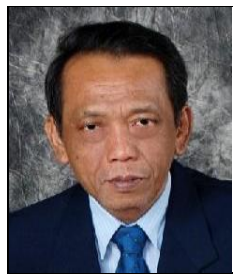

Agusto W Martosudirdjo received a bachelor's degree in physics engineering from Bandung Institute of Technology, Indonesia. He is now researcher in Center for Appropriate Technology Development, Indonesian Institute of Sciences. His research interest is in the field of manufacture engineering.

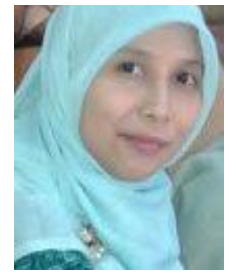

Ira Maryati has a master of professional degree in IT for library from Bogor Agricultural University, Indonesia in 2014. She is now researcher in Center for Scientific Documentation and Information, Indonesian Institute of Sciences. Her research interests include information and knowledge management. 